\title{
Passive Solar Technique Using Trombe Wall - A Sustainable Approach
}

\author{
Piyush Sharma ${ }^{1}$, Sakshi Gupta ${ }^{2}$ \\ '(M.Tech. Scholar, Department of Civil Engineering, Amity University Haryana) \\ ${ }^{2}$ (Assistant Professor, Department of Civil Engineering, Amity University Haryana)
}

\begin{abstract}
This work presents a detailed investigation on a Trombe wall, a solar wall, is an important element of passive solar design. It is a very thick wall and can be south-facing or north-facing depending upon the hemisphere, which is painted black and made of exclusive material that absorbs lot of heat. Trombe walls are enormous 'passive' ways of providing heat to an interior space. The main advantage of Trombe wall is that they are often easily built from locally available materials, very reliable and having less repair, maintenance and operation costs. These walls contribute in reducing heating and cooling costs of a building and hence these are considered as vital technique of sustainable architecture.
\end{abstract}

Keywords - Solar Energy, Sustainability, Thermal mass, Thermal comfort, Trombe wall.

\section{INTRODUCTION}

Utilization of energy and its conservation has become prime concern due to ever increasing global warming effect. Energy can be very well conserved if utilized properly in buildings by application of various techniques. In high rise buildings, large amount of the energy is consumed for air conditioning and heating as well as for running a number of appliances of daily use. Energy consumed for heating in buildings has the largest proportion of consumption i.e. nearly $45 \%$ which needs to be continuously evaluated so as to reduce the energy utilization and make a sustainable environment [1]. In passive design, the location and orientation of buildings and the characteristics of building materials are taken into account that helps in providing good thermal comfort by cutting down the heating, cooling and electricity costs. For many centuries, a number of people have used thick walls of adobe or stone to trap the sun's heat/energy during the day time and release it eventually and evenly at the night time to warm the buildings [1].

Trombe walls are mainly suited for sunny climates that have high day-night temperature swings. Today small scale energy efficient buildings are developed on an ancient technique that incorporates a thermal mass and efficient delivery system called Trombe wall which continues to serve as an effective feature of passive solar design. The essential idea was first investigated by Edward S. Morse and patented by him in the year 1881 . In the late 1960s it was fully developed and recognized as a sustainable architectural element by French engineer named Felix Trombe. Good thermal comfort can be created reasonably in the building with such a system (Trombe Wall) [2]. .Many analytical and experimental researches have been done on the heat transfer, warmth mechanism, dynamics and performance analysis of Trombe wall [3].

\section{TeChNicAl ASPECTS Of Trombe WALL}

A common Trombe wall consists of the following features/technical aspects:

- $10-41 \mathrm{~cm}$ thick masonry wall is painted with a dark, heat absorbing color that is mostly black in color.

- Covered with an insulated glass (double glazing) or low emissivity glass (Low e-glass).

- The glass is put at $2-5 \mathrm{~cm}$ far from the masonry wall in order to make small air space.

- It must be South facing.

- For houses in the southern side of the equator, Trombe walls should be installed in a north-bound direction for maximum efficiency and greatest effectiveness, as that is the side which will be exposed to the most sunlight. 
- Heat from sun passes directly through the glass, absorbed by the dark surface, stored in the wall and then it gradually moves inward in the masonry through conduction as shown in fig. 1.

- High transmission glass boosts solar gains to the masonry wall.

- The glass layer prevents the escape of radiant heat from the warm surface of the storage wall.

- The air gap traps the heat radiated by the wall, leading to further heating of the wall surface.

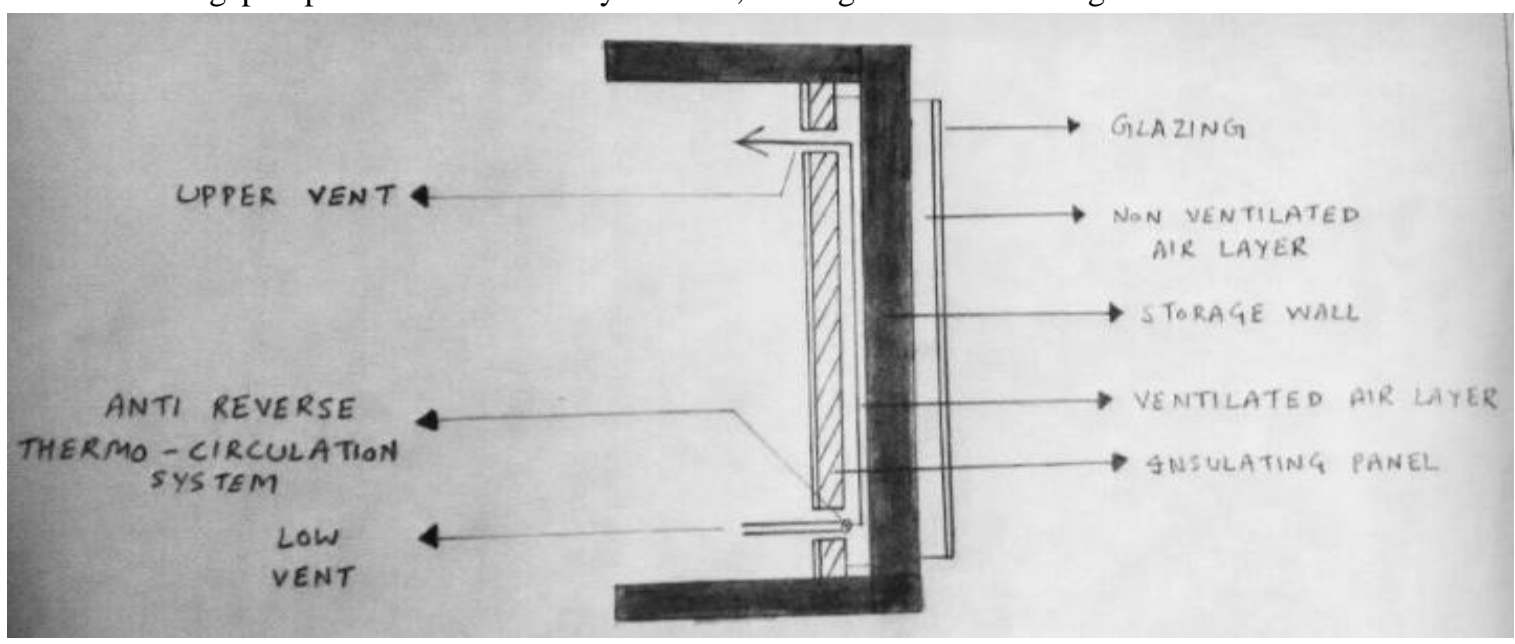

Fig. 1: Cross section of a Trombe wall.

For a $20-\mathrm{cm}$ Trombe wall, heat will take around 8 to 10 hours to reach the inside of the building. This means that rooms receive gradual and even heating/warmth for many hours after the sun sets, highly decreasing the demand for conventional heating. Trombe walls can be successfully use in residential living areas and bedrooms. Upper and lower air vents can be used in the wall which allows convection currents, as cooler air from the room enters at the bottom and air heated by the trombe wall bypassing the room at the top. Both vents must be serviceable to prevent reverse convention currents which occur at night, for cooling the engaged space [4]. Windows installed in a trombe wall may diminish the efficiency of wall, but they may be installed for lighting or aesthetic purposes. Detailed technical specifications of Trombe wall are listed in Table 1.

TABLE I Technical specifications of Trombe wall [5]

\begin{tabular}{|c|c|}
\hline Technical Specification & Value \\
\hline Orientation & South \\
\hline Wall area ratio $(\%)$ & $0-50$ \\
\hline Windows shading coefficient & $0.90-0.95$ \\
\hline Wall height $(\mathrm{m})$ & $3-3.5$ \\
\hline Wall thickness $(\mathrm{m})$ & $0.25-0.30$ \\
\hline Wall thermal conductivity $\left(\mathrm{W} / \mathrm{m}^{\circ} \mathrm{C}\right)$ & 1.75 \\
\hline Wall specific heat $\mathrm{x}$ density $\left(\mathrm{kJ} / \mathrm{m}^{\circ} \mathrm{C}\right)$ & 1932 \\
\hline Wall solar absorbance & 0.9 \\
\hline Glazing emittance & 0.9 \\
\hline Window R-value $\left(\mathrm{m}^{2}{ }^{\circ} \mathrm{C} / \mathrm{W}\right)$ & 0.333 \\
\hline Space between wall and glazing $(\mathrm{m})$ & $0.15-0.20$ \\
\hline Number of glazing & $1-2$ \\
\hline
\end{tabular}




\section{Working OF A Trombe WALL}

Trombe wall is an "indirect-gain" system which works on the basic greenhouse principle that heat from the sun in the form of "shorter-wavelength \& higher-energy U.V radiation" passes through glass panel in front of the wall and is absorbed by the wall. The air in between the wall and glass is heated through conduction. As air is heated, it passes through the top vent heating the room through convection and at the same time, the cold air is drawn in through the bottom vent heated by the sun and rises up again. This creates a cycle of warm air flow. TRNSYS software is used for modeling of building having Trombe walls [6, 8]. Trombe wall work differently in summers and winters as described below:

a) Trombe walls in the summer: In the summer season, the wall is shaded by the overhang and does not receive direct sunlight. When a Trombe wall is sheltered, it will remain cool and its intrinsic qualities will absorb heat to keep the rest of the place cooler. The immanent materials in such walls are responsible for gradual heat absorption and transfer. The overhang area blocks the summer sun from hitting the Trombe Wall. Objects within the thermal mass can be taken as heat batteries.

b) Trombe walls in the winter: In the winter, when the sunlight hits the wall, the wall gets 'charged' up to warm the house by transferring the sun's heat inside. The thermal mass in the trombe wall will gradually boost as it absorbs heat energy, and then will gently release it. In winters, when the surrounding ambient air temperature drops in the night, the thermal mass will extend to release its stored heat energy which would help the construction to stay relatively warm after the sunset for a longer period of time. After liberating all the heat, it will be ready once again to absorb the heat next day.

Working of Trombe wall is shown in Figure 2.

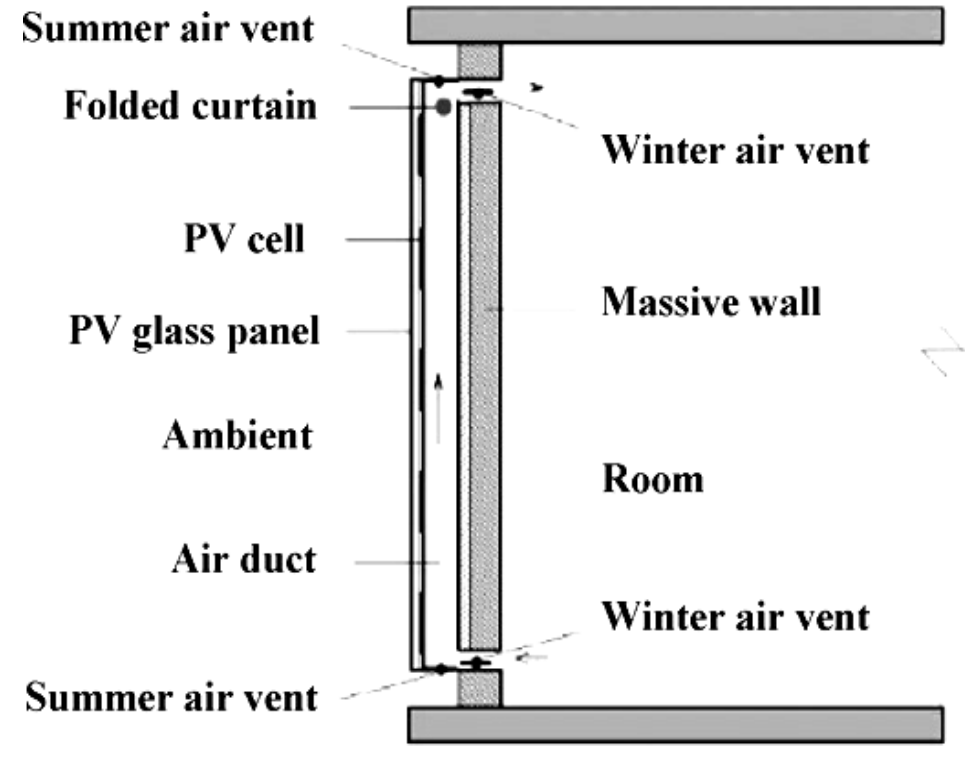

(a)

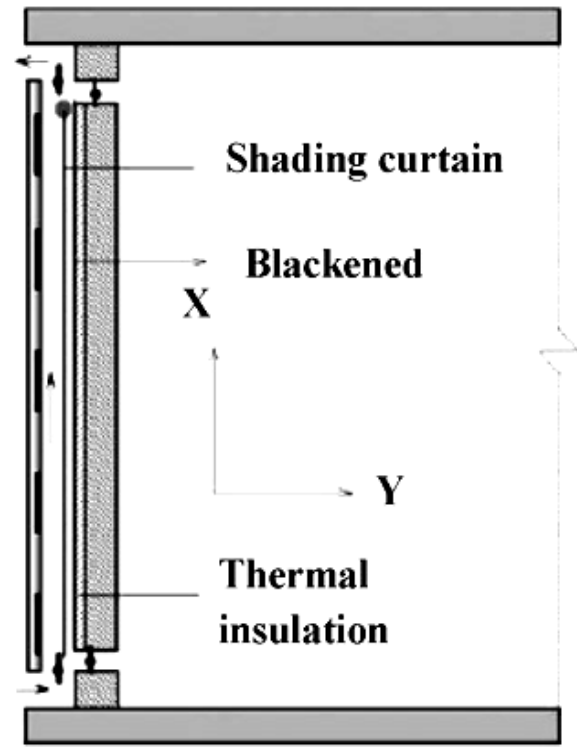

(b)

Fig. 2: Trombe wall for (a) winter heating and (b) summer cooling [6].

\section{Trombe Wall Vs Direct Gain Passive Solar Design}

- The efficiency of Trombe wall in collecting solar heat is not as high as of a direct gain passive solar design of the same dimension.

- Trombe wall is very simple in design having no ducts, controllers and blowers.

- Heat losses during night are less than for direct gain windows.

- The inner surface of the Trombe wall can be used to some extent for acoustic a purpose which is not in the case of direct gain window. 
- Trombe wall does not provide day lighting views as a direct gain window would -- this can be a merit or demerit for Trombe walls.

- In case of existing wall construction, it is easier to retrofit a Trombe or solar wall than to retrofit a direct gain window.

\section{USE OF Trombe WALL IN INDIA}

Climate of India has wide range of weather conditions due to versatile geography and topography in various states. Mainly there are 9 climatic regions in India:

a. Tropic Savanna type climate

b. Tropical Monsoon type climate

c. Tropical Moist climate

d. Semi-arid Steppe climate

e. Hot Desert type climate

f. Mesothemal climate- Gangetic Plain type climate

g. Cold Humid Winter type climate

h. Polar type climate

i. Tundra type climate

Many Indian states offer a good feasibility for Trombe walls. The average outdoor temperature and orientation of sun is good for construction of such walls. Most of the India's regions have a composite climate and shortage of electricity throughout the year which can be a good option for the passive solar construction.

\section{Trombe wall in Ladakh Region}

In Ladakh (India), the state government is designing Trombe walls to promote sustainable construction without comprising with Ladakh's traditional architectural beauty. People are finding such walls as reliable, energy efficient and compatible source of heat. Smoke and cold winds are major concern in Ladakh region due to fuel and dung burning that affects the health of nearby living population to a great extent. Trombe wall provides relief from both the cold winds and the smoke thereby creating a sustainable and eco-friendly environment. Ladakh region receives about 320-325 days of sun annually, and the locally available building materials like stone and mud brick provide the thermal insulation needed in a Trombe wall as shown in Figure 3.

\section{Trombe wall in Gwalior}

The honey storage building situated at Gwalior in India has one fine example of the use of trombe wall. During winter months, the room air temperature of building falls under the required temperature range of 18-27 ${ }^{\circ} \mathrm{C}$ suitable for honey storage. The room air temperature range is maintained in the building using a $2.3 \mathrm{~kW}$ capacity electrical oil filled radiator that accounts for the crucial energy consumption of the building on an annual basis. On account of this, there are significant $\mathrm{CO}_{2}$ emissions into the atmosphere from the honey storage building. This gave rise to a need of new technique and thus, the use of trombe wall.

During winters, the two vents of trombe wall were kept open during the day and closed during the night. During night the vents were also covered with night movable insulation cloth. During summers, completely shade the trombe wall with the movable insulation to avoid heat gain through the trombe wall. Also, it was recommended to go for shading of roof of the building/construction to reduce the unreasonable heat gain. The use of Trombe wall prove its relevance for natural heating of the building in winter months and passive heating of building provides an opportunity for conserving appreciable amount of electrical energy for heating the room air for honey storage requirement [6]. 


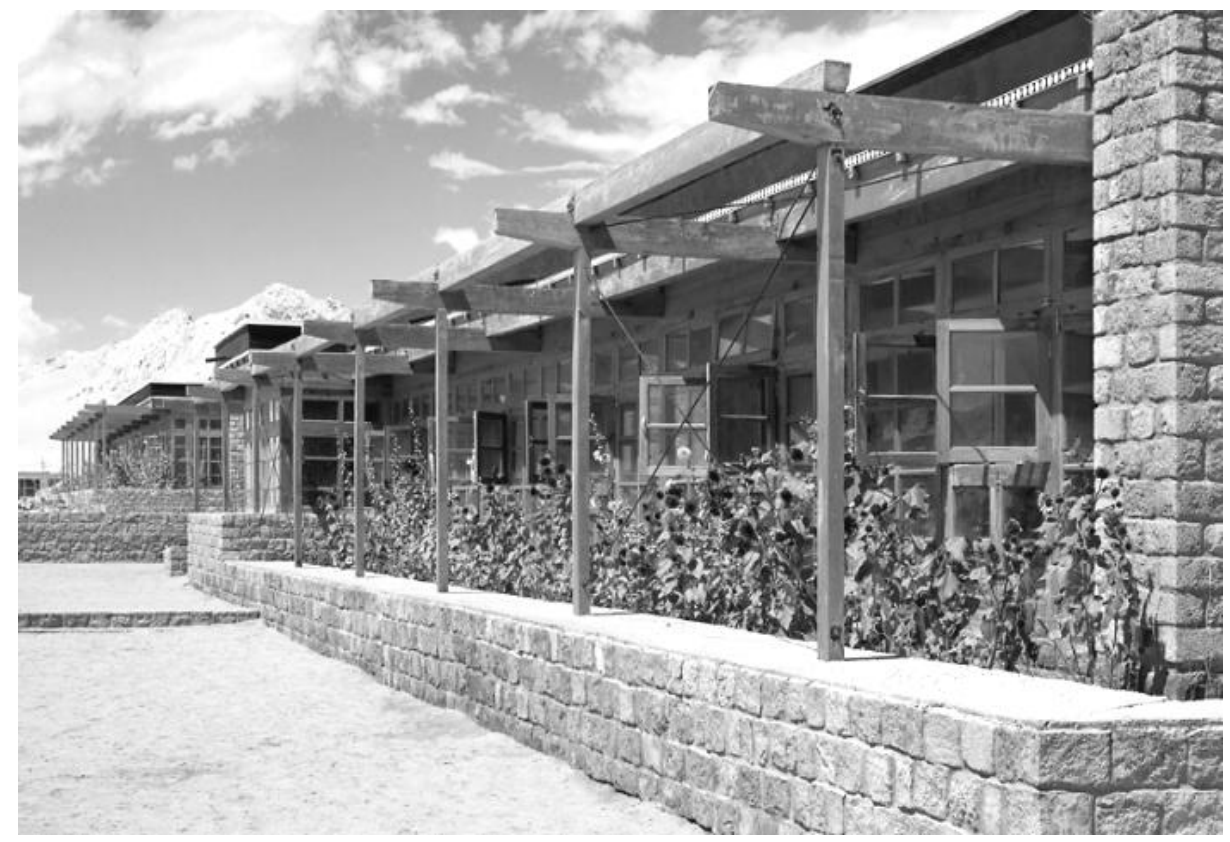

Fig. 3: Energy efficient Trombe walls at Druk white lotus school, Ladakh, India [9]

\section{ECONOMical ASPects Of Trombe Wall}

Before constructing any building element, the cost and benefits are considered as the prime importance. The economics of Trombe wall is dependent on many variable factors such as climatic condition, cost of materials, cost of manpower, cost of energy and type of construction. Benefits of trombe wall can be seen as high energy conservation, reduction in $\mathrm{CO}_{2}$ emissions and creating ventilation in sub floor spaces. According to Ji Jei et al. a trombe wall can cater $20 \%$ of house/building heating demands. Trombe wall is primarily meant for long term customer benefits [7]. Arvind Chel et al. carried out an extensive study on "Honey Storage Building" in India and concluded that trombe walls can save up to 3312-3320 KWh/year of energy, $\mathrm{CO}_{2}$ emissions can be cut by approximately 33-35 tonnes in an Indian storage honey building and retrofitting such buildings is also economically sound as payback period is around 7-8 months only [6].

\section{CONClUSion AND RECOMMENDATIONS}

As per the design aspects and working, the following can be the advantages of Trombe walls:

- These walls provide adequate and pleasant heating than other traditional heating systems.

- It provides free heating when once installed.

- It takes or makes use of existing wall space.

- It is completely passive in design with minimum or no maintenance.

- It is very easy to construct with even semi skilled labor.

- Trombe walls can reduce heating bills by large amounts and can improve average electrical efficiency by $10-15 \%$

- It is best suited in regions having good solar energy resources and large winter heating requirements.

With every new design there are always some of the disadvantages along with the advantages. The following are the disadvantages:

- It can be costly to install Trombe walls.

- It has to be carefully designed.

- Overheating is also a frequent and a familiar trouble during the hotter summer months, but this can be mitigated as long as one ensures that the thermal mass wall of suitable thickness to absorb the excess heat.

Thus, Research on glazing materials, coating materials and aesthetic appearance is suggested so as to have cost effective wall and give maximum efficiency. Awareness regarding benefits of Trombe wall is recommended in developing countries. 


\section{REFERENCES}

[1] T.G Özbalta and S. Kartal, "Heat gain through Trombe wall using solar energy in a cold region of Turkey", Scientific Research and Essays, 5(18), 2010, 2768-2778.

[2] N.M. Thanu, R.L. Sawhney, R.N. Khare and D. Buddhi, "An Experimental Study of the Thermal Performance of an Earth-Air-Pipe System in Single Pass Mode", Solar Energy, 71(6), 2001, 353-364.

[3] J. Jie, Y. Hua, H.Wei, P. Gang, L. Jianping and J. Bin, "Modeling of a Novel Trombe Wall with PV Cells", Building and Environment, 42(3), 2007, 1544-1552.

[4] S. Omiderza, K. Sopian, C.H Lim and M.Y Suleiman, "Trombe walls: A review of opportunities and challenges in research and development", Renewable and Sustainable Energy Reviews, 16(8), 2012, 6340-6351.

[5] S. Jaber and S. Ajib, "Optimum design of Trombe wall system in Mediterranean region", Solar Energy, 85(9), 2011, 1891-1898.

[6] A.Chel, J.K. Nayak and G. Kaushik, "Energy conservation in honey storage building using Trombe wall", Energy and Buildings, 40(9), 2008, 1643-1650.

[7] J. Jie, Y. Hua, P. Gang and L. Jianping, "Study of PV-Trombe wall installed in a fenestrated room with heat storage", Applied Thermal Engineering, 27(8), 2007, 1507-1515.

[8] M.A. Kamal, “An Overview of Passive Cooling Techniques in Buildings: Design Concepts and Architectural Intervention”, Acta Technica Napocensis: Civil Engineering \& Architecture Journal, 55(1), 2012, 84-97.

[9] T.Gyalsan, Druk White Lotus School, Ladakh, India - A Case Study, Intelligent Buildings International, 1, 2009, $82-96$. 